\title{
'n Praktiese-teologiese ondersoek na prediking en die effek van sosiale kognisie in die handeling van kontek-stualisering
}

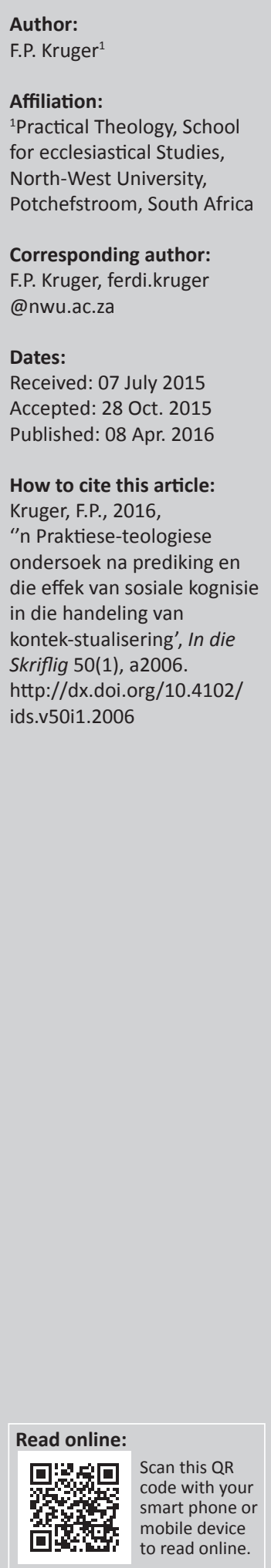

A practical theological investigation on preaching and the effect of social cognition in the act of contextualisation. It is indicated in recent research that church and society are conscious of each other through their observation of one another - a process also known as social cognition. This article intends to investigate the manner in which the church is observing society. The following research question is stated: Which role can preaching play to foster good neighbourship in society and what is the aspects that influence the cognition of the church as community of believers? This research will be undertaken from a practical-theological vantage point. This field of research shows a tangency with the fields of Ecclesiology and Missiology. From these two fields the importance of the practical-theological field of research will be indicated. This research will further investigate the problematic praxis through an intradisciplinary discourse with the field of Social Psychology. In this exposition it will be indicated that the founding and functioning of social cognition is a natural process although it also has it complexities. From a normative vantage point investigation on Jeremiah 29 and Matthew 5 will be undertaken in order to state that the right cognition is important for internalising sermons and the conveyance of sermons into daily life. Distortions, in the process of social cognition, can also cultivate a wrong view on what it entails to be salt and light in the world. Practical-theoretical perspectives on the benefit of a good name in society will be provided that will be favourable for the preaching of the Word.

\section{Inleiding}

Immink (2014:177) sowel as Verweij (2014:225) benadruk die feit dat prediking binne'n omvattende raamwerk van 'n konteks ${ }^{1}$ (liturgies, linguisties, die samelewing en die kulturele) waarbinne dit geskied, beskou moet word. Prediking moet in die lig van God se Woord 'n beroep op die gemeenskap doen wat meebring dat die voorbeelde en toepassing in preke relevant vir die konteks van hoorders moet wees (Immink 2014:176; Verweij 2014:226). Dit spreek vanself dat die kerk $^{2}$ betrokke moet raak by die vestiging van die regte waardes, maar dit moet op sodanige wyse gedoen word dat hoorders in die erediens en mense in die samelewing dit sal verstaan (Rossouw 1993:898). Die vestiging van waardes moet sin maak vir die hoorders sodat die boodskap kragtig uitgedra kan word. 'n Boodskap wat goed begryp word, word makliker aan andere oorvertel.

Om kontekstueel waarde toe te voeg, vereis die regte tipe kognisie of, anders gestel, die regte waarneming van die samelewing deur die kerk as vergadering van gelowiges. Hierdie aspek van sosiale kognisie, naamlik die wyse waarop die samelewing die kerk as 'n geloofsgemeenskap waarneem, verdien nadere ondersoek in navorsing. Met die begrip kognisie ${ }^{3}$ word bedoel die natuurlike neiging wat by mense bestaan om sin te wil maak uit dít wat van ander mense waargeneem word (Fiske 2004:121). Hierdie doelbewuste poging om rekening te hou met die kultuur word deur Immink (2014:178) beskryf as 'n verbinding tussen die Woord en die wêreld waarin gelowiges leef.

Die probleem waarmee kerke (plaaslik) in die praktyk gekonfronteer word, is hoedanig die gelowiges beginselvas met 'n nuwe kultuur (kultuur as 'n lewensstyl van die breë gemeenskap) moet omgaan (Beale 2008:295). Die uitdaging wat aan die handeling van prediking gestel word, is hoedanig die teks

1.Die begrip konteks verwys na alle relevante aspekte wat daartoe meewerk dat gemeenskappe en individue gevorm word en die begrip kultuur is nou hieraan verwant (vgl. Ott \& Strauss 2010:267).

2.Onder die begrip kerk (gelowiges) word verstaan die heilige, algemene eenheid van gelowiges wat saamgebind word deur die geloof in Christus. Die kerk het ' $n$ sigbare of plaaslike asook 'n onsigbare gestalte. In hierdie sin van die woord is die kerk' $n$ vrug van die koninkryk (koningskap) van God.

3.Onder kognisie word verstaan die proses waarin mense nadink oor hulleself, oor mense en oor hulle sosiale omstandighede met die doel om hieruit sin te maak (vgl. Fiske 2004:122). 
van die Woord en die konteks waarin hoorders leef, bymekaar gebring kan word om nuwe perspektiewe vir hoorders beskikbaar te stel (Tubbs-Tisdale 1997:39). Tubbs-Tisdale (in Long \& Tubbs-Tisdale 2008:90) het die spanningsveld rondom die begrip kultuur aangevoel. Sy toon aan dat die kerk as gemeenskap van gelowiges nie in isolasie bestaan nie (vgl. Tubbs-Tisdale 1997:11). Enige plaaslike kerk bestaan en funksioneer binne die fisiese omgewing van 'n buurt, 'n dorp, 'n stad, 'n volk en die wêreld. Volgens Ott en Strauss (2010:266) is dit juis hierdie besef wat kontekstualisering as 'n proses noodsaak waarin die altydgeldende waarheid van die Woord met die altydveranderende konteks in verband gebring word. Die persoon van die prediker wat die Woord verkondig, asook die hoorder wat na die preek luister, is blootgestel aan 'n bepaalde kultuur, 'n aspek wat deur Herrington, Greech en Taylor (2003:30) beskryf word as die 'our wired togetherness'. Dit is in hierdie opsig waar navorsing oor sosiale kognisie 'n waardevolle bydrae tot die handelingsondersoekveld van prediking kan lewer.

Hierdie artikel stel dit ten doel om prakties-teologiese perspektiewe te ontgin wat die praksis van kerkwees binne die omgewing en die kultuur waarin elke dag geleef word te verryk. Daarom sal daar op die rol gefokus word wat gelowiges kragtens hulle waarneming binne die konteks van hulle direkte omgewing moet vertolk. Gelowiges moet kragtens die wese en aard van die kerk op ekonomiese, politieke, sosiale en kulturele gebied as 'n nuwe gemeenskap (liggaam van Christus) binne die wêreld funksioneer (Heitink 2007:28-30). Dit is onvermydelik dat gelowiges deur middel van eredienste ${ }^{4}$ (liturgie) en die prediking toegerus sal word om te begryp dat, benewens hulle fisiese adres en kerkgebou, hulle ook deel van 'n groter kulturele konteks uitmaak (Long \& Tubbs-Tisdale 2008:93). Die volgende navorsingsvraag word geïdentifiseer: Watter rol behoort die prediking en, as deel hiervan, die proses van sosiale kognisie te speel om beter buurmanskap te bevorder en watter aspekte kan moontlik as oorsake dien waarom hierdie aspek nie tot sy reg kom nie?

In hierdie artikel word op kwantitatief-deduktiewe wyse te werk gegaan deur vanaf die teoretiese aspekte wat reeds ontwikkel is ten opsigte van die ondersoekveld, verder ondersoek in te stel na die praktyk van die handeling van prediking. Daar word op eklektiese wyse met die literatuur omgegaan. Die metode hou in dat toepaslike materiaal, veral uit die vakgebiede van Missiologie en Sosiale Psigologie, deur analise en interpretasie gekeur en gerangskik sal word om in te pas in die opset van die navorsing. In die metodologiese aanpak sal die navorsing op die voetspoor van Dingemans (1996:62) in drie fases geskied:

- die analiserende of ontledende beskrywing van die prakties-teologies situasie;

- die ondersoek na normatiewe gesigspunte; en

- die ontwikkeling van veranderingstrategieë op grond van die beskrywing van normatiewe uitgangspunte

4. Onder 'erediens' word verstaan die ontmoeting met God; en 'liturgie' word verstaan as die handelinge wat deur gelowiges onder die erediens verrig word en gedurende die week voortgesit moet word in die diens van die lewe.
Tydens die eerste fase van die navorsing word daar eerstens voorbeelde van navorsing en refleksie rondom die probleemveld in oënskou geneem; tweedens word die bestaande teologiese invalshoeke en grondslae vir kontekstualisering in ag geneem; en derdens word metateoretiese waarnemings gemaak oor sosiale kognisie in die dinamika van gelowiges se bydrae tot die kultuur waarin hulle leef. In die tweede fase word die normatiewe gesigspunte waaruit die belangrikheid van buurmanskap benadruk word ondersoek. In die derde fase sal praktykteoretiese perspektiewe gebied word op die belangrikheid van goeie buurmanskap in die handeling van die verkondiging van God se Woord.

\section{Analiserende of ontledende beskrywing van die spanningsveld Voorbeelde van navorsing rakende hierdie probleemveld in die gereformeerde denkwêreld.}

In die Praktiese Teologie, met 'n sterk gerigtheid op handelinge wat ondersoek word, gaan dit ook oor handelinge in die samelewing (Heyns \& Pieterse 1991:19). Hierdie gerigtheid op die samelewing (kontekstualiteit) het oor die jare verskeie benaminge ontvang:

- Trimp (1984:23) plaas die klem op aktuele prediking;

- Runia (1983:11) het op sy beurt besin oor die eiesoortige kultuur-historiese konteks waarin hoorders gekonfronteer word met 'n tydsgewrig en kultuur wat kompleks is sodat daar nooit oorvereenvoudig kan word nie;

- Van Ruler (1989:105) plaas die term teonome-resiprositeit op die agenda van die Praktiese Teologie waarin hy die klem op die resiprositeit tussen God en mens plaas;

- Venter (2005:218) skryf op sy beurt oor die hermeneutiese wisselwerking tussen die preekteks uit die Woord van God en die teks van die hoorders se lewens;

- Pieterse (2007:130) vra die vraag hoe God aan die woord kan kom deur die prediking. Hy toon aan dat dit noodsaaklik is om aktueel en met vrymoedigheid die lewensvrae van die tyd te ondersoek.

- Masango en Pieterse (2008:135) beskryf die prediking in die erediens onder andere as 'n geleentheid tot 'n refleksie op die gemeente se ervaring van God se teenwoordigheid in hulle dienswerk binne die gemeenskap.

Vanuit hierdie kort oorsig wil dit voorkom asof die kontoere van kontekstualisering ${ }^{5}$ wel binne die Praktiese Teologie van belang is. Oor die teologiese grondslae van kontekstualisering (die begrip wat gekies word in hierdie artikel) en die kerk se betrokkenheid in die spanningsveld van die kultuur van die gemeenskap is die afgelope aantal jare wyd besin. Dit wil voorkom asof verskillende nuanses vanuit resente literatuur voortdurend hieraan toegevoeg word. Vanuit die seleksie uit die literatuur blyk die aktualiteit en omvangrykheid van hierdie spanningsveld.

5. In hierdie artikel word 'kontekstualisering' verstaan as die poging om doelbewus by die kultuur aansluiting te soek met die oog daarop om die Woord te kommunikeer sodat mense dit sal verstaan (vgl. Ott \& Strauss 2010:283) 
Die volgende insigte oor die rol van die kerk teenoor die samelewing word as relevant geag:

- Buchanan (2012:21) spreek kommer uit oor die kerk wat in die samelewing van irrelevansie beskuldig word as gevolg van 'n terughoudendheid om oor sensitiewe aangeleenthede te preek.

- Keller (2012:194) spreek kommer uit daaroor dat gelowiges op verskillende wyses teen die kultuur in die samelewing kan reageer:

- 'n terugtrek uit die wêreld in die veilige ruimte van die gemeenskap van die gelowiges;

- die soektog na 'n Christus vir die kultuur;

- die soeke na 'n Christus verhewe bo die kultuur;

- die dualistiese strewe om gelowiges te beskou as burgers van die koninkryk van God sowel as die samelewing; en

- 'n strewe om die kultuur in alle opsigte in 'n Christuskultuur te wil verander.

- Wilkerson (2012:41) fokus op die rol van inspirerende prediking wat onder andere inhou dat die inhoud van die prediking aan die toepassing op gelowiges se lewens in die omgewing waarbinne hulle woon, gekoppel moet wees. Sodoende word beklemtoon dat 'n weerklank in die prediking moet plaasvind tussen die inhoud van preke en die 'gewone' mense op straat.

- Pieterse (2009:250-274) bemerk op eie bodem 'n verleentheid by Afrikaanssprekende kerke om God in die huidige konteks ter sprake te bring. Hy begrond sy siening op drie faktore:

- die ingrypende veranderinge in 'n nuwe bedeling sedert 1994 met ' $n$ nuwe regering en nuwe hoofde binne die werksplek en die aandrang op regstellende aksie wat meegewerk het dat mense hulle werk verloor het;

- die rol van postmodernisme op die prediking. 'n Sterk antikerklike gees het onder baie Suid-Afrikaners posgevat. Aan die ander kant bemoeilik 'n materialistiese strewe en gees die roeping van die kerk;

- 'n rasgebonde manier waarop regstellende aksie toegepas word met die gevolg dat die arbeidsmark vir baie mense uitsigloos geword het.

Bogenoemde aspekte het ' $n$ invloed op die kognisie van die kerk sowel as die samelewing.

Brouwer (2008:26-28) het navorsing gedoen oor prediking in konteks en beklemtoon dat konteks 'n breë en omvattende begrip is. Hy toon aan dat elke plaaslike kerk haarself in 'n spesifieke poskodegebied bevind met haar onderskeie lidmate wat hulle weer binne 'n geografiese wyk bevind. Hierdie lidmate word op talle maniere beïnvloed (positief of negatief) deur die mense in hulle omgewing.

Long (2005:51) gee in sy uiteensetting oor wat prediking behels aandag aan die konteks daarvan. Prediking is vir hom 'n handeling wat nie net binne die konteks van die erediens geskied nie, maar ook binne die konteks van die wêreld (samelewing) daarbuite: op die markplein, op straathoeke, in gevangenisse, hospitale asook in openbare plekke. Hiermee benadruk Long die belangrikheid van prediking as 'n wyse van getuienislewering. Predikers moet op priesterlike wyse die behoeftes, omstandighede en nood van die gemeente asook die wêreld onder die vergrootglas van die teks plaas.

Van der Walt (2010:61) vestig die aandag op die funksionering en geloofwaardigheid van geloofsgemeenskappe binne die Suid-Afrikaanse samelewing en die eise wat ' $n$ aspek soos byvoorbeeld armoede stel.

De Klerk (2014:49) benadruk die feit dat die liturgie wat gelowiges naloop deelname aan die daaglikse liturgie in die samelewing tot gevolg moet hê. Juis daarom moet die liturgie nie die samelewing klakkeloos navolg nie, maar mag dít wat gelowiges met die liturgie verrig ook nooit só lewensvreemd en anders wees dat dit mense in die samelewing nie raak nie.

\section{Bestaande teologiese invalshoeke en grondslae vir die beoefening van die handeling van kontekstualisering}

Die besinning oor die handeling van kontekstualisering kan vanuit verskillende invalshoeke plaasvind vanweë die duidelike raakvlakke met die ander skakeringe van die teologiese studievelde. Daarom wil hierdie navorsing erkenning gee aan die feit dat daar moontlik vanuit onder andere die Ekklesiologie en Missiologie 'n eiesoortige perspektief op die problematiek geplaas kan word. Die teologie is immers ' $n$ ondeelbare eenheid en daarom word met veral hierdie vakgebiede in gesprek getree. Verskillende dissiplines word in veranderende tye genoodsaak om te besin oor die verhouding tussen kerk en samelewing. Die vraag ontstaan of die Praktiese Teologie wat die kommunikatiewe handelinge in diens van die evangelie ondersoek, wel moet kennis neem van hoedanig Dogmatiek en Missiologie oor die wese en identiteit van die kerk besin.

\section{Besinning vanuit 'n ekklesiologiese hoek}

Heitink (2007:24) toon vanuit 'n prakties-teologieseekklesiologiese hoek aan dat besinning oor die wese en die eienskappe van die kerk histories gesproke dikwels voortgespruit het uit 'n problematiese praksis. Daarom spreek Heitink (2007:25) kommer daaroor uit dat daar, volgens hom, vanuit die hoek van die ekklesiologie oënskynlik 'n gebrekkige bydrae oor die debat van stagnasie in kerke gelewer word. Navorsing oor die prakties-teologiese ekklesiologie het byvoorbeeld ' $n$ hernieude visie op die vier funksies van kerklike bediening, naamlik kerugma, leitourgia, koinonia en diakonia geplaas (vgl. Breytenbach \& Pieterse 1992:103). Besinning oor die ekklesiologie is immers noodsaaklik in prakties-teologiese navorsing (Breytenbach \& Pieterse 1992:102).

Du Plooy (2014:10) toon aan dat die kerk 'n instelling van God is en daarom die eiendom van God. Hierdie kerk (eiendom van God) bestaan uit 'gewone' mense. Helberg (2014:20) voeg by dat God sy koninkryksheerskappy in belang van sy kinders uitoefen en dat Hy dit in en deur hulle doen. Vir Helberg (2014:21) gaan dit daaroor dat die 'amp' van die mens nooit belangriker as die persoon self is nie en 
dat mense geskep is om in al sy lewensfasette in God se diens te wees. Die kerk word met eienskappe (notae ecclesiae) versier: die eienskappe van eenheid, heiligheid, algemeenheid (katolisiteit) en apostolisiteit (Du Plooy 2014:11). Van der Merwe (2014:11) voeg by dat die kerk as vergadering van gelowiges (plaaslik sowel as wêreldwyd) aan haar doel beantwoord in die mate waarin sy dit regkry om hierdie eienskappe te toon.

Van Engen (1991:37) doen reg aan die praktiese implikasies hiervan deur aan te toon dat' $n$ verskuiwing in ekklesiologiese nadenke ingetree het - spesifiek ten opsigte van die taak en plek van die kerk in die wêreld. Hierdie verskuiwing het, volgens Van Engen (1991:37-38), verdere besinning oor 'the real place of the real Church in the real world' voortgebring.

Die eienskappe van die kerk (notae ecclesiae) het in die nuwere besinning die omlyning ontvang van 'n gawe en opgawe karakter. Elkeen van die vier eienskappe is 'n gawe, maar dit is tegelyk ook 'n opdrag. Die kerk van Christus moet derhalwe meer en meer word wat sy reeds in Christus is. Hiervolgens sou dit, volgens Van Engen (1991:65), inhou dat gelowiges hulle opdrag as gelowiges sodanig sal begryp dat hulle ook roepingsbewus in die samelewing sal optree. Om as gestuurdes van God in die wêreld op te tree, moet daartoe aanleiding gee dat God alles en in almal sal wees. Met hierdie stelling haal Van Engen ' $n$ belangrike saak op wat implikasies het vir homiletiese besinning, naamlik dat gelowiges die boodskap van die prediking moet uitdra na alle mense toe.

Binne ekklesiologiese kringe word oor die saak gedebatteer, naamlik of hierdie eienskappe waarna hierbo verwys is na binne beskou moet word en of dit as sodanig geïnterpreteer moet word dat dit in omvattende sin te make het met die wêreld waarbinne die kerk waarlik kerk moet wees. Sonder om in hierdie artikel aan die debat te wil deelneem, wil dit voorkom asof daar in ekklesiologiese kringe toenemend die visie ontstaan dat dit wat gelowiges binne 'n plaaslike kerk doen ook in die samelewing en in die wêreld daarbuite 'n uitwerking moet hê. Dit wil voorkom asof Du Plooy (2014:11) korrek is in sy aanname dat die kerk nie in terme van haar roeping beskryf moet word of selfs ook nie in terme van wat in die wêreld gedoen moet word nie. Wat die kerk kragtens haar wese en aard is, is daarom die kernvraag.

Heitink (2007:32) interpreteer hierdie eienskappe van die kerk vanuit prakties-teologies-ekklesiologiese hoek en toon aan dat die kerk te midde van verdeeldheid in die wêreld opnuut weer moet besin oor die eenheid (wat tussen gelowiges bestaan), die heiligheid (vir God afgesonder), die katolisiteit asook die apostolisiteit van die kerk. Heitink bly egter in gebreke om konkreet hieroor te besin, maar slaag tog daarin om aan te toon dat gelowiges hierin 'n voorbeeld moet stel aan hulle omgewing. Heitink (2007) slaag ook daarin om aan te toon dat die rol van die prediking in die belewing van hierdie eienskappe nie geringgeskat kan word nie. Gelowiges moet met woord en daad die Woord van God aan alle mense bring en in besonder aan mense binne hulle direkte omgewing. Die waarde van Heitink se bydrae is daarin opgesluit dat hy vanuit 'n ekklesiologiese hoek die saak benadruk, naamlik dat plaaslike kerke doelbewus 'n verhouding met die mense in die omgewing moet opbou om sodoende die boodskap wat verkondig word, geloofwaardig te maak.

\section{Besinning vanuit Missiologiese hoek}

Stetzer en Putman (2006:5) besin oor die konvergensie tussen globale en lokale kontekste om 'n 'glocal' konteks te vorm. Die kerk moet in 'n veranderende konteks daarmee rekening hou dat mense in die gemeenskap nie noodwendig meer na die kerk toe stroom nie. Volgens Stetzer en Putman (2006:111 bestaan daar ' $n$ weerstand teen die kerke en die boodskap wat die kerk verkondig. Herrington et al. (2003:87) pleit daarvoor dat kerke opnuut weer sal besin oor waarom hulle doen wat hulle doen en sodoende die waarde van roeping sal besef. Keller (2012:183) toon aan dat dit vroeër makliker was om mense in die samelewing kerk toe te bring, aangesien dit vir baie mense sin gemaak het. Hierdie kultuur het intussen verander sodat die kerk tans 'n kultuurskok beleef. Die kognisie tussen kerk en wêreld is aan verandering blootgestel.

Ott en Strauss (2010:266) toon aan dat, deur die proses van kontekstualisering, die kerk in staat gestel word om deur die uitleef van die geloof in God Drie-enig, 'n kongruensie te laat ontstaan tussen die teks (Woord) en die kulturele konteks waarbinne hoorders lewe. Daarom het die proses van kontekstualisering te make met die wyse waarop die Woord van God en die kultuur mekaar ontmoet. Die hoorders van die evangelie beskik immers oor 'n eie kultuur en 'n eie agtergrond (Stetzer \& Putman 2006:7). Indien Woordverkondiging en die kerklike bediening nie rekening hou met die konteks van hoorders nie, word die realiteit in die samelewing verwaarloos (Herrington et al. 2003:96).

Reeder (2008:16) belig 'n belangrike aspek wanneer hy die gevare bespreek van 'n kerk met 'n slegte naam en 'n reputasie binne die omgewing of samelewing. Ander gelowiges en ongelowiges binne 'n omgewing beskik immers oor persepsies van 'n plaaslike kerk. Gelowiges wat 'n plaaslike kerk verlaat, kan dikwels nie wag om hulle storie aan ander mense te vertel nie. Dit bring Reeder (2008:17) by die vraag of gelowiges aan hulle bure en aan mense binne hulle omgewing die regte boodskappe voorleef en vertel. Kultuur het immers, onder andere, 'n sigbare aspek, naamlik die manier waarop mense optree asook die dinge wat hulle voortbring (Ott \& Strauss 2010:267). Eetgewoontes, werksetiek en die wyse waarop God aanbid en gedien word, is iets wat kwalik vir ander mense verberg kan word (Beale 2008:294). Dit bring Beale (2008:16) by die punt waar hy aantoon dat mense dít word wat hulle aanbid. 'n Goeie naam en goeie buurmanskap in die omgewing word nie in die eerste plek deur nuusbriewe en dokumentasie gestaaf nie, maar primêr uit dít wat mense in die omgewing dink en sê van 'n plaaslike kerk (Reeder 2008:17). Dit wat bure van gelowiges dink, maak wel saak. Juis daarom is navorsing oor die aspek van kognisie belangrik. 
Op grond van bogenoemde insigte waar die klem geplaas is op die wese van die kerk as 'n gemeenskap van gelowiges en die belangrikheid van ' $n$ goeie naam binne die omgewing waar gewoon en gewerk word, ontstaan die noodsaak om intradissiplinêr kennis te neem van die belangrikheid van sosiale kognisie. Daarom wil die artikel erkenning gee aan die intradissiplinêre benadering wat meebring dat navorsingsresultate vanuit die sosiale wetenskappe geïntegreer word in hierdie ondersoek (Cartledge 2003:15).

\section{Metateoretiese insigte vanuit die Sosiale Psigologie oor sosiale kognisie as die proses waardeur ander mense verstaan word}

In die Sosiale Psigologie is die vermoë van mense om ander binne sekondes op te som en sin te maak uit dit wat hulle waarneem, meermale nagevors. Die gevaar bestaan immers dat dít wat van ander mense waargeneem word, verkeerd kan wees (Eysenck \& Keane 2010:571; Fiske 2004:121). Sosiale kognisie dui op die proses waardeur mense indrukke vorm oor andere se persoonlikheid en optrede sodat nadenke ontstaan oor die waarde wat ander mense tot jou lewe toevoeg (Barker \& Angelepoulo 2010:67; Baron \& Byrne 1994:108). Fiske (2004:122) som die begrip kognisie op deur die volgende stelling: 'It is amazing that people manage to make sense of each other, in milliseconds, but it is terrible the errors that people sometimes commit.'

Volgens Fiske (2004:123) sowel as Louw en Louw (2007:303) het die proses van kognisie te make met begrip en hoedanig ander mense verstaan word. In hierdie verstaansproses (hermeneutiese proses) dink mense na oor ander met die oog op sinvolle interaksie. Die implikasie van bogenoemde insigte is dat mense voortdurend besig is om inligting oor ander mense te versamel en dat juis hierdie inligting mense se verdere optrede beïnvloed. Die versameling van inligting kan vertroue in ander mense skaad en juis daarom is dit van belang dat predikers en gelowiges hiervan moet kennis neem. Om in die samelewing die Woord van God op effektiewe wyse te kommunikeer, moet predikers hulle hoorders sodanig begelei dat die vrees vir die tendense in die samelewing nie voorop staan nie, maar eerder die voorreg om binne die omgewing van God te kan getuig.

Gass en Seiter (2003:115) vestig die aandag daarop dat veral twee soorte kognisies die alledaagse lewe beïnvloed, naamlik outomatiese gedagtes asook onderliggende aannames. Hulle (Gass \& Seiter 2003:138) bemerk'n gevaar in hierdie kognisies, naamlik die totstandkoming van kognitiewe distorsies of vertekenings. Hieroor merk Gass en Seiter (2003) die volgende op (vgl. ook Bergh \& Theron 2006:374; Louw \& Edwards 1998:549):

In oorveralgemening dink mense op 'n globale en oordrewe inklusiewe wyse. Indien ' $n$ ander persoon byvoorbeeld van jou godsdienstige opinie verskil, kan die veralgemening gemaak word dat die persoon nie van jou hou nie. Die veralgemening kan verder inhou dat hierdie persone opponente is. Arbitrêre gevolgtrekkings word gemaak waartydens mense tot ' $n$ slotsom kom oor sake waaroor hulle nie afdoende getuienis het nie.
Selektiewe abstraksie of afleiding behels dat daar bloot op ' $n$ deel van wat plaasgevind hetgefokus word terwyl die res geïgnoreer word. In die alles-of-niks-denke (polariserende denkpatrone) word geredeneer dat mense óf waarde het óf dat hulle nie waarde toevoeg nie. (bl. 139)

Wat is die rede vir die funksionering van hierdie kognitiewe distorsies of vertekenings? Die rol van vroeëre wanaangepaste skemas lê aan die wortel daarvan (Fiske 2004:143; Sternberg \& Pretz 2010:11). Aan die hand van skemas as verwysingsraamwerk word nuwe inligting verwerk (Barker \& Angelepoulo 2010:67). Hierdie skemas word dikwels reeds vroeg in die kinderjare gevorm en kontinueer in later jare om 'n persoon se gedagtes en gevoelens te beheers. Hierdie outomatiese gedagtes en aannames wat onakkuraat kan wees, het dikwels 'n negatiewe impak op die wyse waarmee met ander mense omgegaan word. Negatiewe sosiale kognisies word sodoende selfvervullende voorspellings wat moeilik is om te verander (Schwartz \& De la Rey 2004:493). Die vraag ontstaan of hierdie tendens nie neerslag vind in die wyse waarop gelowiges in die samelewing optree en die wyse waarop die wêreld teenoor die kerk reageer nie. Hoedanig raak hierdie verskynsel die handeling van die prediking?

Hierbo is aangetoon dat sosiale kognisie die begrip is vir die wyse waarop oor ander mense, sosiale verhoudings en sosiale instellings gedink word (Louw \& Louw 2007:304). Vanuit navorsing oor sosiale kognisie spruit die aspek van perspektiefneming voort, naamlik die vermoë om 'n situasie vanuit 'n ander persoon se perspektief te beskou (Louw \& Louw 2007:304). Volgens Louw en Louw (2007:305) behels perspektiefneming die vermoë om 'n situasie vanuit ander persone se perspektief te benader. Hierdie vermoë om perspektief te vorm, wissel van ouderdomsgroep tot ouderdomsgroep. Vanuit bogenoemde beredenering blyk dit dat eerste indrukke, ook indrukke gevorm in die kinderjare, belangrik is. Sosiale kognisie is 'n aspek waarvan die Praktiese Teologie moet kennis neem in die kommunikatiewe handelinge wat ondersoek word. Mense verstaan en interpreteer die samelewing waarbinne hulle leef aan die hand van skemas. Hierdie skemas kan aangeleer word uit direkte ervaring, maar ook via die vertelling van ander mense (Fiske 2004:166). Briscoe (1994:80) het ten slotte die volgende waarneming (kognisie) van die kant van die samelewing gemaak: Die wyse waarop die mens sy samelewing waarneem en beleef, beïnvloed die wyse waarop hy of sy in die omgewing optree.

Drie verdere aspekte wat met kognisie verband hou, raak die mens se kontak of reaksie teenoor die omgewing:

- Privaatheid: Mense is geneig om hulle van ander te wil afsluit. Dit handel heimlik oor die mag wat mense wil uitoefen oor die hoeveelheid interaksie met ander mense. Hierdie aspek kan nadelig wees vir die wyse waarop koinonia ervaar word. Dit kan ook ook 'n gebrekkige ywer vir die dienswerk in die kerk tot gevolg hê.

- Territorialiteit: Hierdie aspek het te make met die besetting van 'n bepaalde sfeer of gebied deur 'n groep mense. Hierdie gebied het die karakter van 'dit is ons 
$\mathrm{s}^{\prime} \mathrm{n}^{\prime}$ en word beskerm teen indringing van ander mense. Teologies gesproke kan die neiging ontstaan dat die kerk laer trek teenoor die wêreld wat boos en sleg is.

- Persoonlike ruimte: Dit het te make met die gemaklike afstand wat mense dikwels tussen hulleself en andere wil handhaaf. Mense word dikwels op beperkte wyse naby aan jou toegelaat. Hierdie aspek van persoonlike ruimte het beslis implikasies vir die wyse waarop met ander gekommunikeer word.

\section{Normatiewe perspektiewe op die belangrikheid van betrokkenheid in die samelewing}

Stott (1999:17) toon in sy ondersoek na die Skriftuurlike basis vir gelowiges se belangstelling in die samelewing aan dat gelowiges óf die werklikheid kan ontvlug óf dit deel van hulle lewens kan maak. 'n Derde moontlikheid sou ook kon bestaan, naamlik die gevaar van akkommodasie. Die derde moontlikheid word nie in hierdie navorsing bespreek nie, alhoewel dit wel relevansie toon met hierdie ondersoekveld. In die onderafdelings wat volg, sal aandag geskenk word aan die belangrikheid van God se koninkryk, die noodsaaklikheid om 'n kerk vir die strate te wees (sout en lig) en die soek na vrede vir die stad. In hierdie onderafdeling word aandag gegee aan drie aspekte, naamlik die mens in God se koninkryk, normatiewe aspekte op bevordering van die stad se belange (sjaloom) asook die invloed wat gelowiges op die gemeenskap moet uitoefen. Die bedoeling hiermee is om aan te toon dat die visie van God se koninkryk gelowiges verantwoordelik maak ten opsigte van hulle eie optrede asook hulle verantwoordelikheid in die gemeenskap.

\section{Die mens in God se koninkryk}

Floor (1981:81) het aandag gegee aan die sosiale aspek van God se koninkryk. Hy toon aan dat die koninkryk van God op aarde gestalte kry in die kerk wat 'n nuwe gemeenskap is van almal wat Jesus Christus as hulle Here en Verlosser bely. In hierdie gemeenskap van gelowiges word die ware koinonia of te wel egte societas [gemeenskap] beoefen (Floor 1981:81-82). Vorster (2011:36) toon op sy beurt aan dat mense wat tot die koninkryk toetree geensins passiewe deelgenote is nie. Hulle word eerder sunergoi [medewerkers] vir die koninkryk. Op grond hiervan het Stott (1999:73) gewys op die invloed wat gelowiges in die samelewing het. Die koninkryk van God waarvan gelowiges deel is, is een wat alle ander koninkryke oortref. Gelowiges het 'n roeping in die samelewing deur die uitleef van die koninkrykswaardes en die uitdra van die Koningswoord aan almal binne die omgewing met die buurt waar hulle woon as vertrekpunt (Stott 1999:73). Onder die term koninkryk van God word verstaan die dinamiese regering van God oor alles en almal wat gehoorsaam moet word. Die kerk as gemeenskap van gelowiges is 'n vrug of gestalte van die gehoorsaamheid aan die koningskap van God (Spoelstra 1989:5).

Vos (1995:110) verbind die prediking aan die ruimte waarbinne dit tot sy reg kom, naamlik dié van die erediens. Wepener (2009:190) merk op dat 'n erediens waarin die besef van God se teenwoordigheid ontbreek, nie aanspraak op die naam erediens kan maak nie. Die erediens waarvan die prediking ' $n$ belangrike element is, verkondig immers die boodskap van die evangelie van God se koninkryk (Vos 1995:107). Gelowiges is deur die erediens besig om God se koningskap te vier. Hierdie besef moet gelowiges se handelinge tydens die erediens en daarna beïnvloed. Deur die verkondiging van die evangelie van die koninkryk van God word gelowiges opgeroep om hulle in die geloof aan God se koningskap te onderwerp (Vos 1995:109). De Klerk (2014) beskryf op die voetspoor hiervan die saak soos volg:

The aim of preaching is not merely that those on the other end should listen, but that there should be a change in attitude and that the listeners should be empowered to be preachers themselves and to carry the sermon further. (p. 9)

Nóú verbonde aan hierdie besef is die gedagte dat gelowiges, in die uitdra van die boodskap van God se koningskap en oproep tot onderwerping aan die Koning, rekening sal hou met die eskatologiese verwagting wat om die twee pole 'reeds' en 'nog nie' wentel. Prediking moet daarom bydra tot die hoorders se vooruitsig na God se toekoms wat reeds vandag begin (Keith 2015:7). Hierdie besef plaas die verantwoordelikheid op predikers en hoorders om die Woord van God kragtig te kontekstualiseer binne die omgewing waarin hulle hulself bevind (Vos 1995:111). As gevolg hiervan beklemtoon Cilliers (2004:17) die noodsaaklikheid daarvan dat gelowiges die wêreld waarin hulle leef in die lig van God se wêreld (koninkryk) moet sien - 'n wêreld wat in Christus reeds aangebreek het. Enige waarneming (kognisie) van die werklikheid rondom gelowiges begin eers by die sien van die onsienlike God.

\section{Normatiewe perspektiewe op 'bevorder die belange (sjalom) van die stad' (Jer 29:7)}

Bakke (1997:85) bemerk in die boodskap van Jeremia 29 iets wat kontrasterend was met die openbare mening van die tyd. Die ballingskap was vir die mense 'n tragedie, maar God het 'n nuwe begin vir die volk in vooruitsig gehad. Die ballinge word bemoedig om hulle in ' $n$ vreemde land tuis te mak deur huise te bou, tuine te maak, in die huwelik te tree en kinders in die wêreld te bring (Manser 2010:1142) Die volk moes in 'n vreemde land optree soos wat hulle in hul eie land sou optree. Volgens Bakke (1997:85) was Juda nie die slagoffer van omstandighede nie, maar was hulle deel van God se sending in Babel. Laubscher (1991:179) bemerk in hierdie gedeelte sprake van moontlike twyfel by die Judese volk oor hulle optrede in 'n samelewing met vreemde gebruike en godsdienstige oortuigings. Gornik (2010:101) beskryf op sy beurt dat die opdrag van Jeremia 29:7 meebring dat die volk hulle nie van die samelewing in 'n vreemde land mag onttrek nie. Die begrip sjalom (Jer 29:7) word in hierdie gedeelte aan 'n normale en rustige lewe verbind. God se volk moes nie die onaangename omstandighede op passiewe wyse aanvaar nie, maar op aktiewe wyse die belange van die stad bevorder (Keller 2012:171). Greenway en Mashau (2007:42) bemerk in die begrip sjalom dat enigiets wat in die pad van 
'wholeness' staan, die sjalom bedreig. Buite die lewende God is daar geen sprake van 'heelwees' nie. Dit is die taak van die kerk om die boodskap van sjalom in die gemeenskap te leef en te verkondig (Greenway \& Mashau 2007:43). Trouens, die kerk moet haar hiervoor beywer.

Die volk moes vra na die sjalom van die stad. Die begrip vra beteken om iets te vra of om na iets te verlang (Jenni \& Westermann 1984:459). Aan die einde van Jeremia 29:7 word die opdrag gegee om vir die stad te bid, want die welsyn van die stad is ook in die volk se belang. Die opdrag sou ook weergegee kon word met 'want in die vrede van die stad, sal julle vrede vind'. Die begrip vrede (sjalom) word drie keer in Jeremia 29:7 gebruik. Pop (1964:547) bemerk 'n omvattende betekenis in die begrip sjalom. Die welsyn van die stad waarvoor die volk hulle moes beywer en waarom hulle moes bid, sluit sake in soos gesondheid en gestabiliseerde verhoudings in die politiek en sosiale lewe. Die begrip sjalom benadruk sodoende die noodsaak van hegte verhoudinge en ordelikheid (Pop 1964:547). Gelowiges moet verantwoordelikheid neem vir mense in die samelewing en sodoende na hulle belange omsien (Laubscher 1991:180). Die welsyn van die gemeenskap is belangrik en ' $n$ biddende lewenshouding is hiervoor noodsaaklik. Sjalom word op sy duidelikste bemerk in die wyse waarop mense met mekaar omgaan en is tekenend van die atmosfeer waarbinne gelowiges elke dag moet lewe (Pop 1964:549). Laubscher (1991:182) benadruk die belangrikheid van die feit dat vrede drie keer in Jeremia 29:7 ter sprake is. Hy benadruk dit ook dat sjalom die harmonieuse verhouding met God asook die vreugde daarin om Hom te kan dien as beginpunt het. In die tweede plek bring hierdie regte verhouding met God die regte verhouding in die samelewing voort wat voortspruit uit 'n roepingsgedrewe wees van dít wat ons reeds is.

Greenway en Mashau (2007:46) benadruk die feit dat gelowiges vir die sjalom van die stad (gemeenskap) moet bid. Volgens hulle (Greenway \& Mashau 2007:47) beteken dit dat die gebede van die gemeenskap vir die sjalom daarop neerkom dat gebid en gepreek moet word vir die erkenning van God se koningskap in die samelewing. Die gebed van die kerk vir die samelewing moet sodanig wees dat God se koninkryk sal kom in elke gevangenis, op die markplein, in elke parlementsgebou en in elke omgewing waar gelowiges hulle bevind (Greenway \& Mashau 2007:47). Gornik (2010:99) benadruk die gedagte dat die prediking van God se Woord juis die besef van sjalom moet bring. Dit hou in dat hoorders binne die samelewing voorbeelde moet wees van hoedanig harmonieuse verhoudings daarna uitsien. Die opdrag aan gelowiges om hulle te beywer vir die vrede van die stad en om te bid hiervoor, is'n kragtige boodskap aan die wêreld (Gornik 2010:99).

\section{Normatiewe perspektiewe op die invloed van gelowiges}

\section{Matteus 5:13-16 (sout en lig)}

Sout en lig is van die noodsaaklikste alledaagse vereistes (Manser 2010:1410). In Matteus 5:11-13 word die gesindheid van die wêreld teenoor die gelowiges geplaas teen die agtergrond van vervolging. Jesus se visie van die wêreld is meer omvangryk en daarom vestig Hy in die twee metafore wat gebruik word die aandag op die invloed wat sy koninkryk op die wêreld uitoefen (Tasker 1984:62). Manser (2010:1411) bemerk in die twee metafore van sout en lig 'n tweeledige doel: Gelowiges is anders as wat die wêreld is; en gelowiges is nóú aan hierdie wêreld verbonde.

Stott (2007:138-144) bemerk die volgende drie aspekte in die gebruikmaking van die metafore van sout en lig:

- Onderliggend aan die metafore is die gedagte dat die wêreld donker is en dat daar dinge is wat bederf aanhelp. Die kerk word geroep om in die wêreld te dien as sout en lig. Die wêreld kan nie sonder die lig en die sout van die kerk nie.

- Gelowiges moet die wêreld penetreer. Lig skyn in die duister en sout werk in die voedsel. Die kerk mag nie soos lig in 'n vertoonkas wees of soos soutpotte in 'n spens nie. God se kinders moet bedag wees op die geleenthede om as sout en lig by die werk, in die skool en op enige plek waar hulle hul in die gemeenskap bevind op te tree. Gelowiges moet deelnemers aan die liturgie van die lewe wees.

- Sout en lig is selfs in klein hoeveelhede effektief. Daar waar sout en lig in kontak kom met hulle omgewing, is daar verandering. Duisternis word verjaag, voedselbederf word gekeer en goeie smaak word aan kos gegee.

Om as sout en lig in die wêreld op te tree, bring mee dat moeite gemaak moet word met die verkondiging van God se Woord (Manser 2010:1410). Te midde van die realiteit in die wêreld wat meebring dat God se koningskap nie erken word nie, moet gelowiges op andersoortige wyse die wêreld waarneem (kognisie). Alhoewel gelowiges hulle altyd in alles aan koninkrykswaardes moet onderwerp, moet hulle roepingsgetrou wees ten opsigte van hulle voorbeeld en hulle verkondiging van God se koningskap aan alle mense (Stott 2007:149). Die kerk word geroep om die wêreld te beïnvloed sodat elkeen wat die lig sien en die sout proe, God sal verheerlik. Deur die opdrag om sout en lig te wees, moet mense God se Naam verheerlik. Die metafore van sout en lig moet elke kind van God anders na die wêreld laat kyk. Deur die lewende verkondiging van die Woord moet die lig skyn en die wêreld voorsien word van dít wat die bederf keer. Die kerk mag nooit hande vou en die wêreld op eensydige wyse verwyt vir al die bederf en duisternis wat bestaan nie. Deur sout en lig te wees moet ' $n$ dors na die lewende Woord en 'n soeke na die lig daarvan by die wêreld geskep word. Die kerk is kragtens haar wese geroep om kontak met die wêreld te hê, want juis in die kontak en uitreik is die roeping om sout en lig te wees opgesluit.

Keller (2012:169) toon op grond van die opdrag om sout en lig te wees aan dat die betrokkenheid van gelowiges in die wêreld altyd 'n dubbele ontdekking maak: Deur gelowiges se betrokkenheid by en belangstelling in ander mense, word daar kennis gemaak met diesulkes wat baie met jou 
ooreenstem, maar tog verskillend in optrede en sienings is. Aan die ander kant word mense ontmoet wat radikaal van jou opinies en menings verskil.

Die enigste wyse waarop gelowiges op kragtige wyse kan reageer op grond van hulle samelewingskognisie is om nog meer soos sout en lig op te tree. Volgens Keller (2012:169) is dit die kognisie van dít wat in die samelewing plaasvind wat predikers en gelowiges bemagtig om die krag van die evangelie op kreatiewe wyse te verkondig. Om sout en lig te wees, vra 'n nuwe sensitiwiteit. Stott (2007:143) benadruk in hierdie opsig die verkeerde gesindheid van gelowiges om die wêreld vir alles wat verkeerd is te wil blameer. Die duisternis en verrotting in sedes en waardes wat meermale waargeneem word (kognisie), moet gelowiges nog kragtiger aanspoor om roepingsbewus as sout en lig op te tree.

\section{Veranderingstrategiese perspektiewe op die funksionering en verandering van kognisie}

Vanuit die bogenoemde navorsing het dit geblyk dat die kerk geroep is om in die wêreld betrokke te wees. Die realiteit van die samelewing moet roepingsbewus (as sout en lig) benader word deur die waardes van die koninkryk van God te verkondig. Die kerk moet die duidelike gelaatstrekke van God se koninkryk in die wêreld openbaar. Die kerk word geroep om haarself te beywer vir die harmonieuse verhoudinge in die samelewing. Die aandag is op die begrip sosiale kognisie gevestig. Hierdie begrip het te make met die wyse waarop gelowiges en die wêreld mekaar waarneem. Hieruit blyk die noodsaak dat die kerk nie die wêreld as 'sonde met die bure' moet ervaar nie, maar eerder daarna moet streef om kontekstueel verhoudinge te help bou. Vanuit hierdie hermeneutiese wisselwerking tussen die normatiewe en metateoretiese aspekte word die aandag vervolgens op slegs twee aspekte gevestig met die inagneming daarvan dat daar heelwat meer mag bestaan Die volgende praktykteoretiese aspekte verdien vervolgens aandag:

\section{Prediking binne die ruimte van omgee (koinonia of societas) vir die hoorders en die samelewing as dryfveer vir kontekstuele prediking}

Pieterse (2001:98) omlyn die uitdaging aan predikers om effektief te kommunikeer deur die saak binne die raamwerk van die konteks waarin hoorders hulleself bevind te plaas. Die hoorders van preke leef in 'n unieke konteks van gevoelens, oortuigings, gesindhede en sieninge oor God en die wêreld. Pieterse (2001:102) voeg by dat die prediking as 'n aspek van die sfeer van gemeentelike aktiwiteite binne die ruimte of konteks van die erediens geskied, maar tog is dit so invloedryk dat alle ander aspekte daardeur geraak word. De Klerk (2001:60) verduidelik die verhouding tussen liturgie en kultuur deur die verband daartussen en waarbinne hoorders hulleself bevind te verklaar. De Klerk (2001:64) toon aan dat sekere aspekte van die kultuur in die liturgie benut kan word, terwyl ander aspekte van die kultuur juis deur die liturgie getransformeer moet word. Aan die ander kant beskryf Dames (2008:61) die uitdaging aan die liturgie deur op die rol van kulturele veranderinge op hoorders se siening van die lewe en eredienste te wys. Müller (1990:28) benadruk 'n belangrike aspek, naamlik dat elke hoorder die erediens tegemoet gaan met 'n bepaalde stemming wat gedra word deur die waarneming (kognisie) van gebeure asook 'n stemming wat die waarneming (kognisie) van die erediens gaan beïnvloed. Die ervarings wat hoorders met kollegas gehad het, die verhouding met bure, die omstandighede binne die omgewing waar gewoon en gewerk word, dra alles by tot die stemming (atmosfeer) wat geskep word. Die kognisie wat in die hoorders plaasvind, is bepalend vir die atmosfeer van die erediens.

Die erediens waar gelowiges saamkom om aan die liturgie deel te neem, is tegelyk 'n ruimte van omgee. Die erediens is die ontmoeting met God waar gemeenskap met God en gemeenskap met mekaar beoefen word (Müller 1990:11). Juis binne hierdie ruimte van omgee vir mekaar, word die Woord van God verklaar en toegepas. Vos (1995:487) omlyn die funksionering van die prediking onder die erediens deur die aandag op die liturgiese konteks van die preek te vestig. Prediking mag nie van die liturgiese konteks waarbinne dit geskied, losgemaak word nie. Jossutis (1991:61) toon aan dat die kommunikasie tydens die erediens te make het met dit wat in die deelnemers van die liturgie se harte geskied wanneer hulle langs die weg van die erediens begin vra na die sin van lewe. Vos (1995:497) benadruk die feit dat prediking binne die konteks van die liturgie daarna moet streef om die teks van die Woord kontekstueel aan die teks van die lewe te verbind. Elke erediens moet oorloop in die wêreld. Daarom toon Müller (1990:9) aan dat elke erediens van 'n plaaslike kerk 'n venster is waardeur die wêreld (in) kyk na die hoorders, maar die erediens moet ook 'n venster wees waardeur hoorders (deelnemers aan die erediens) met nuwe oë na die wêreld moet (uit)kyk. Hoorders moenie bang gepreek word vir die wêreld nie, maar onder die indruk verkeer dat hulle sout en lig vir die wêreld is en hulle moet beywer vir vrede in hulle omgewing.

Kerk en samelewing het albei sekere persepsies van mekaar wat gevorm is deur jarelange waarneming (kognisie). Die funksionering van distorsies binne kognisie word in die praksis bemerk in die opmerkings wat kerk en wêreld op oorvereenvoudigde wyse teenoor mekaar maak (vgl. Nel 2003:114-116):

- Christene woon eredienste by, maar leef gedurende die week met 'n ander stel waardes. Begrippe soos liefde en vrede is lippetaal en realiseer nie in die praktyk nie.

- Die wêreld is vasgevang in 'n kultuur van Godsverduistering. Die besef van God se teenwoordigheid in mense se lewens word al hoe onduideliker. Die hoorders moet besef dat die wêreld boos is.

Daarom ontstaan die vraag hoedanig die prediking daartoe kan bydra dat gelowiges ' $n$ krag, sout en lig vir die omgewing kan word. 'n Belangrike stap sou wees om langs die weg van 
feestelike eredienste en kragtige prediking moeite te maak om kontekstueel nuwe perspektiewe op die samelewing te open. God se teenwoordigheid in die erediens en die wêreld roep om prediking waarin God se eer verkondig sal word. Gelowiges moet gehelp word om distorsies wat in die verlede deur prediking geskep is sodanig te verander dat die kerk weer word wat sy moet wees. Gelowiges moet opnuut weer leer om om te gee vir wêreld. Die preke moet daarvan getuig dat daar vir gelowiges en vir die wêreld waarin God sy kinders geplaas het, omgegee word. Stott (2007:68) raak 'n belangrike aspek aan, naamlik dat gelowiges op grond van die prediking wat tydens die erediens ontvang is voortaan deur hulle lewenswyse aan die samelewing moet toon dat hulle lewens daardeur verander is. Indien gelowiges se optrede in die gemeenskap die inhoud van hulle boodskap weerspreek, verloor die kerk haar geloofwaardigheid tussen bure in die gemeenskap (Stott 2007:69). Juis daarom moet die Woord van God met die gesindheid van omgee aan alle mense verkondig word (Stott 2007:71). In hierdie sin van die woord moet prediking profeties (getuienis) sowel as pastoraal (omgee) wees.

\section{Verbinding (diakonia) met die samelewing deur middel van kontekstuele prediking as toerusting}

Gelowiges het 'n verantwoordelikheid en roeping om hulle by 'n geloofsgemeenskap te voeg (die plaaslike kerk). Binne hierdie ruimte van gemeenskap of societas [omgeegemeenskap] word gelowiges opgebou deur al die gestaltes van Woordverkondiging. Gelowiges mag egter nooit so na binne gekeer wees dat hulle nie sorgsaam optree teenoor mense wat nie aan die kerk behoort nie (Stott 2008:181). In hierdie artikel is aangetoon dat 'n belangrike vereiste vir kontekstuele prediking die omgee vir hoorders pn die wêreld verlang. Die vraag in hierdie onderafdeling is wat kontekstuele prediking moet bewerkstellig. Is kontekstuele prediking iets anders of selfs miskien 'n nuwe gier van prediking?

Wepener (2009:191) bied 'n eiesoortige perspektief op die kognisie wat by hoorders tydens die erediens ten opsigte van die samelewing moet plaasvind. Hy (Wepener 2009:191) lig onder andere die volgende twee aspekte uit:

- Elke erediens van 'n plaaslike kerk is kontekstueel en dra die kenmerke van plaaslike kulture. Liturgiese inkulturalisasie bring mee dat by sekere elemente van die kultuur aangesluit word, terwyl ander aspekte uitgedaag word. Die ander kant van die munt is eweneens waar. Die kultuur daag op sy beurt sekere elemente van die erediens uit. Hieroor moet plaaslike gemeentes op genuanseerde wyse besin.

- Die plaaslike kerk is God se gestuurdes in hierdie wêreld. Die kerk moet ' $n$ omgeeruimte wees waar mense vanuit die omgewing ontvang en opgeneem word. Dit behels nie dat alles van die kultuur gekondoneer moet word nie, maar dit roep wel om betrokkenheid (verbintenis) en diensbaarheid in die samelewing.

Onder kontekstuele prediking word verstaan dat God se Woord op so 'n wyse aan 'n altyd-veranderende konteks verkondig moet word sodat dit duidelik en verstaanbaar is
(Ott \& Strauss 2010:266). Kontekstuele prediking het nie te make met die feit dat Woordverkondiging aangepas moet word by die kultuur nie, maar juis dat die prediking duidelik in alle aspekte van die kultuurkonteks verkondig sal word. Kontekstuele prediking het ten doel om sodanig te preek dat dit die hoorders daarvan tot dieper nadenke sal stem (Ott \& Strauss 2010:270).

Volgens Ott en Strauss (2010:278) beïnvloed die konteks van die hoorders kontekstualisering veral op drie maniere. Dit beïnvloed die waarneming (kognisie) van hoorders ten opsigte van die prediking. Hierdie kognisie bring mee dat hoorders binne hulle konteks geneig is om sekere aspekte van die Woord skerper waar te neem, terwyl ander aspekte nie raakgelees word nie. Indien die konteks van hoorders te make het met opstandigheid oor dienslewering en sosiale geregtigheid, sal hoorders geneig wees om fyner na boodskappe wat die saak aanraak te let. In gemeenskappe waar korrupsie, honger en armoede minder relevant is, sal hoorders neig om die openbaring daaroor te mis. Daar moet gewaak word daarteen dat prediking nie aandadig word aan tonnelvisie by hoorders nie.

Die konteks bring vrae en probleme na vore wat om antwoorde roep. Indien die prediking nie antwoorde bied nie, word dit elders gesoek. Binne veranderende kontekste word vrae aan die prediking gestel wat tegelyk geleenthede skep om deur middel van die prediking nuwe horisonne te open. Konteks is 'n handige hulpmiddel om God se Woord lewend en kragtig te kommunikeer.

Dorsett (2012:116) toon aan dat kontekstuele prediking hoorders voor uitdagings stel. Die uitdaging wat aan kontekstuele prediking gestel word, is om die teenwoordigheid van God aan hoorders sodanig te verkondig dat hulle die boodskap met hulle saamneem. Die inhoud van hierdie boodskap is nie in die eerste plek wat hoorders nié mag doen nie, maar juis dit wat hulle in die samelewing moet wees (Dorsett 2012:117). Wilkerson (2012:34) beskryf op sy beurt dat kontekstuele prediking hoorders help om anders oor God en die wêreld te dink. Daarom is kontekstuele prediking 'n handeling wat verbinding tussen die Woord en konteks bewerkstellig. Volgens Ott en Strauss (2010:284) vind kontekstualisering nie in 'n vakuum plaas nie, maar juis binne die ruimte van gemeenskap. Dit bring mee dat gelowiges van 'n plaaslike kerk moeite moet doen om hulle bure en mense van ander kulture van naderby te leer ken. Die gevaar bestaan dat die kerk op eensydige wyse kan waarneem en in hulle waarneming hulleself skuldig aan distorsie kan maak. Mense probeer om sin uit ander mense se optrede te maak en daarom moet gelowiges versigtig wees vir die gevaar van distorsies in hulle waarneming.

Kontekstuele prediking is prediking wat hoorders bind aan hulle konteks en omgewing. Kontekstuele prediking bring mee dat inkulturalisasie van prediking in die kultuur plaasvind (Flemming 2005:307). Die agent in hierdie proses van inkulturalisasie is die gemeenskap van gelowiges (kerk). Juis daarom moet die kerk deur middel van eredienste en prediking 
nie waag om die samelewing te wil boetseer nie, maar moet juis op kragtige wyse die boodskap van God se koninkryk wat reeds gekom het en nog sal kom, aan elke kultuur verkondig. Gelowiges moet deur die prediking opgeroep word om agente of getroue getuies van hierdie goeie boodskap te wees. Deur middel van kontekstuele prediking moet hoorders die noodsaaklikheid van goeie verhoudings met hulle bure in hulle eie omgewing besef.

\section{Slot}

Die navorsingsvraag of gelowiges genoegsaam toegerus word vir goeie buurmanskap in die samelewing, het hierdie navorsing langs die weg van vier fokuspunte geneem, naamlik die rol van verkondiging (kerugma), die prominente plek van die erediens (leitourgia), die noodsaak van egte societas (koinonia) asook die gesindheid van dienswerk in die samelewing (diakonia). Die belangrike rol van kontekstualisering as ' $n$ wyse waarop verkeerde kognisies by die kerk en samelewing verander kan word, is behandel. Hieruit het geblyk dat kontekstualisering nie te make het met die feit dat die kerk die kultuur van die samelewing moet boetseer nie, maar wel dat 'n inkulturalisasie deur middel van Woordverkondiging binne die heersende kultuur of kulture moet plaasvind sodat die koningskap van God duidelik sal weerklink. In hierdie proses is dit van uiterste belang dat die kerk moeite sal maak om goeie verhoudinge met bure in die gemeenskap te help bou deur waarlik om te gee en bereidwillig sal wees om onbaatsugtig te dien. Kognisie van die samelewing is noodsaaklik, maar dit hou in dat die kerk haar taak en plek as die liggaam van Christus sal begryp. Deur middel van die prediking moet God se Woord op helder en verstaanbare wyse (kontekstueel) verkondig word met die oog op inkulturalisasie van die prediking binne die konteks van die hoorders.

\section{Erkenning \\ Mededingende belange}

Die outeur verklaar dat hy geen finansiële of persoonlike verbintenis het met enige party wat hom nadelig kon beïnvloed in die skryf van hierdie artikel nie.

\section{Literatuurverwysings}

Bakke, R., 1997, A theology as big as the city, InterVarsity Press,_Downers Grove, IL.

Barker, R. \& Angelepoulo, G., 2010, Integrated organisational communication, Juta, Cape Town

Baron, R.A. \& Byrne, D., 1994, Social psychology: Allyn \& Bycan, Boston, MA.

Beale, G.K., 2008, We become what we worship. A Biblical theology of idolatry, Apollos, Nottingham.

Bergh, Z. \& Theron, A., 2006, Psychology in the work context, Oxford University Press, Cape Town.

Breytenbach, H.S. \& Pieterse, H.J.C. 1992, 'Doelwitte vir gemeentebou in die lig van 'n prakties-teologiese-ekklesiologie', Praktiese Teologie in Suid-Afrika 7(2) 'n prakties-

Briscoe, D.S., 1994, Fresh air in the pulpit, InterVarsity Press, Grand Rapids, MI.

Brouwer, R., 2008, 'Preken in context over de homiletische situatie', in M. Barnard, F. Borger, K. Bregman, R. Brouwer, G. van EK, G. Immink, et al. (eds.), Als een leerling leren preken, pp. 21-35, Uitgeverij Boekencentrum, Zoetermeer.

Buchanan, M., 2012, 'Preaching in the city of man', in F. Chan, J. Ortberg, T. Keller, M. Buchanan, A.G. Lotz, M. Driscoll, et al. (eds.), Prophetic preaching, pp. 19-29, Hendrikson Publishers, Peabody, MA.

Cartledge, M.J., 2003, Practical theology-charismatic and empirical perspectives, Paternoster, Londen.
Cilliers, J., 2004, Die genade van gehoorsaamheid, Lux Verbi, Kaapstad.

Dames, G.E., 2008, 'Missional encounter of the gospel engaging cultural edges as agents of adaptive change', Praktiese Teologie in Suid-Afrika 23(1), 55-79.

De Klerk, B.J., 2001, 'Wisselwerking tussen liturgie en kultuur in Suid-Afrikaanse konteks: enkele vertrekpunte', Praktiese Teologie in Suid-Afrika 16(2), 57-75.

De Klerk, B.J., 2014, Liturgical involvement, Potchefstroom Theological Publications, Potchefstroom.

Dingemans, G.D.J., 1996, Manieren van doen: inleiding tot de studie van de praktische theologie, Kok, Kampen.

Dorsett, L., 2012, 'Challenging hearers. Prophetic preaching', in C.B. Larson, (ed.), Prophetic preaching, pp. 105-119, Hendrikson Publisers, Peabody, MA.

Du Plooy, A. R., 2014, 'Wat glo en bely ons van die kerk van Jesus Christus?', Die Kerkblad, Mei, bl. 10, 11.

Eysenck, M.W. \& Keane, M.T., 2010, Cognitive psychology, Psychology Press, New York.

Fiske, S.T., 2004, Social beings: A core motives approach to social psychology, Wiley, Princeton, NJ.

Flemming, D., 2005, Contextualization in the new testament, InterVarsity Press, Downers Grove, IL.

Floor, L., 1981, Die evangelie van die koninkryk, NG Kerkboekhandel, Pretoria.

Gass, R.H. \& Seiter, J.S., 2003, Persuasion, social influence and complaince gaining, Pearson, Boston, MA.

Gornik, M.R., 2010, To live in peace: Biblical faith and the changing inner city, Eerdmans, Grand Rapids, MI.

Greenway, R.G. \& Mashau, D., 2007, An eye that sees: Vision for urban missions, Thistshi, Potchefstroom.

Heitink, G., 2007, Een kerk met karakter: Tijd voor heroriëntasie, Kok, Kampen.

Helberg, J.L., 2014, 'Koninkryk, kerk en teologie in 'n stukkende wêreld', Die Kerkblad, Junie, bl. 20, 21.

Herrington, J., Greech, R.R. \& Taylor, T., 2003, The leader's journey: Accepting the call to personal and congregational transformation, Jossey Bass, San Fransisco, CA.

Heyns, L.M. \& Pieterse, H.J.C., 1991, Eerste tree in Praktiese Teologie, Gnosis, Pretoria.

Immink, F.G., 2014, The touch of the sacred: The practice, theology and tradition of Christian worship, Eerdmans, Grand Rapids, MI.

Jenni, E. \& Westermann, C., 1984, Theologisches handwörterbuch zum Alten Testament. Sjalom, Kaiser Verlag, München.

Jossutis, M., 1991, Der weg in das leben. Ein einführungin den Gottesdienst, Verlag, München.

Keith, D., 2015, 'Preaching for church renewal', Calvin Theological Seminary 22(2), 5-8.

Keller, T., 2012, 'A new kind of urban preacher', in C.B. Larson, (ed.), Prophetic preaching, pp. 169-194, Hendrikson Publishers, Peabody, MA.

Laubscher, J.A., 1991, 'Mens en omgewing', in C.J.A. Vos \& J.C. Müller, (reds.), Bybelse aardrykskunde, bl. 178-185, Perskor, Doornfontein.

Long, T. \& Tubbs-Tisdale, L., 2008, Teaching preaching as a Christian practice, John Knox, Louisville, KY.

Long, T.G., 2005, The witness of preaching, Westminster John Knox, Louisville, KY.

Louw, D. \& Edwards, D., 1998, Sielkunde: $n$ Inleiding vir studente in Suider-Afrika, Heinemann Continued Education, Louisville, KY.

Louw, D. \& Louw, A., 2007, Die ontwikkeling van die kind en die adolossent, ABC Drukkers, Bloemfontein.

Manser, M.H., 2010, The new Matthew Henry commentary, Zondervan, MI.

Masango, M.J.S. \& Pieterse, H.J.C., 2008, 'Liturgy on the edge of Community', Praktiese Teologie in Suid-Afrika 23(2), 124-145.

Müller, J., 1990, Die erediens as fees, NG Kerkboekhandel, Pretoria.

Nel, M., 2003, 'Verantwoordelike evangelisasie in die teenwoordigheid van God: ' $n$ teologiese refleksie', Praktiese Teologie in Suid-Afrika 22(1), 98-118.

Ott, C. \& Strauss, S.J., 2010, Encountering theology of mission, Baker House, Grand Rapids, MI.

Pieterse, H.J.C., 2001, Prediking in 'n konteks van armoede, Unisa, Pretoria.

Pieterse, H.J.C., 2007, 'Hoe kom God aan die woord in die prediking: Die werklikheid en taal waarin ons oor God praat', Praktiese Teologie in Suid-Afrika 22(1), 118-134.

Pieterse, H.J.C., 2009, 'Deelname van gemeentelede aan die prediking: 'n Herbesinning', Praktiese Teologie in Suid-Afrika 23(1), 250-274.

Pop, F.J., 1964, In Bybelse woorde en hun geheim, Sjalom, Boekencentrum, S'Gravenhage.

Reeder, H.L., 2008, From embers to a flame: How God can revitalize your church, P\&R Publishing Company, Phillipsburg, NJ.

Rossouw, G.J., 1993, 'Theology in a post modern culture: Ten challenges', Hervormde Teologiese Studies 49(4), 894-907.

Runia, K., 1983, The sermon under attack, Paternoster, Exeter.

Schwartz, L. \& De la Rey, C., 2004, Introduction to psychology, University Press, Oxford.

Spoelstra, B., 1989, Gereformeerde Kerkreg en Kerkregering, Hammanskraalse Teologiese Skool, Pretoria.

Sternberg, R.J. \& Pretz, J.E., 2010, Cognition and intelligence, University Press, Cambridge. 
Stetzer, E. \& Putman, D., 2006, Breaking the missional code: Your church can become a missionary in your community, Broadman \& Holman Publishers, Nashville, TN.

Stott, R.J.W., 1999, New issues facing Christians today, Zondervan, Grand Rapids, MI.

Stott, R.J.W, 2007, The living church, InterVarsity Press, Nottingham.

Stott, R.J.W., 2008, Wat moet ek glo?, InterVarsity Press, Nottingham.

Tasker, R.V.G., 1984, The General Epistle of James, Eerdmans, Grand Rapids, MI. (Tyndale New Testament Commentaries).

Trimp, C., 1984, De gemeente en haar liturgie, Van den Berg, Kampen.

Tubbs-Tisdale, L., 1997, Preaching as local theology and folk art, Fortress, Minneapolis, MN.

Van der Merwe, R.M., 2014, 'Die ekumenisiteit van die kerk', Die Kerkblad, Junie, bl. 11

Van der Walt, B.J., 2010, When African and Western cultures meet, The Institute for Contemporary Christianity in Africa, Potchefstroom.
Van Engen, C., 1991, God's missionary people: Rethinking the purpose of the local church, Baker Books, Grand Rapids, MI.

Van Ruler, A.A., 1989, Theologisch werk, Nijkerk, Callenbach.

Venter, C.J.H., 2005, 'Prediking wat transformeer: prakties-teologiese gesigspunte', In die Skriflig 39(2), 217-237.

Verweij, A., 2014, Positioning Jesus' suffering: A grounded theory of lenten preaching in local parishes, Eburon, Den Haag.

Vorster, J.M., 2011, Menswaardigheid, versoening en vergiffenis, Potchefstroomse Teologies Publikasies, Potchefstroom.

Vos, C.J.A., 1995, Die blye tyding, RGN, Pretoria.

Wepener, C., 2009, 'Ontdek die draaipunte in die geskiedenis van liturgie', in C. Burger F. Wessels, S. Joubert, D. Smit, \& Barnard, M. (reds.), Ontdekkings in die erediens, bl. 190, 191, Lux Verbi, Wellington.

Wilkerson, B., 2012, 'Preaching with vim, not just vigor', in C.B. Larson (ed.), Inspirational Preaching, pp. 33-43, Hendrikson Publishers, Peabody, MA. 